\title{
Writing Responses to Controversial Topic in ELT: A Case of High Order Thinking Skill Development in an Indonesian Vocational School
}

\author{
Z. W. Lestari, Y. Firmansyah, N. Noviantoro, Fajar Khoerul, Hendi Syahmadi \\ \{zzz_wijilestari76@yahoo.com ${ }^{1}$, yadi.firmansyah@fkip-uninus.ac.id ${ }^{2}$,n.noviantoro@gmail.com ${ }^{3}$, \\ fajarchairul24@gmail.com ${ }^{4}$, hendi_syah@yahoo.co.id ${ }^{5}$ \} \\ English Education Department, Universitas Islam Nusantara, Bandung, Indonesia ${ }^{1,2,3}$, SMKN 6 \\ Bandung, Indonesia ${ }^{4}$, SMAN 20 Bandung, Indonesia ${ }^{5}$
}

\begin{abstract}
The professional environment requires not only appropriate expertise in the field, but also human resources capable of adapting to thinking skills. Vocational school's curriculum begins to integrate the concept of critical thinking in the 2013 curriculum. This research was done to explore the possibilities of controversial topics to stimulate students' thinking skills. As many as 33 students were involved in this study and their written responses were analyzed with text analysis adapting Bloom's taxonomy framework. The results of the study show that controversial topics are able to stimulate students to respond to a problem with a more complex mindset than they normally do. Their response writing shows that by connecting limited background knowledge, they begin to see problems from different sides. It is recommended to further explore the use of controversial topics to promote students' critical thinking yet advise further research on how far controversial topic may be implemented in Indonesian EFL context.
\end{abstract}

Keywords: controversial topic, high order thinking skills, written response.

\section{Introduction}

The vocational school curriculum directs graduates to work in accordance with the required competencies in the professional world. To realize this, Technical and Vocational Education (TVE) integrating the curriculum needs to prepare the required additional skills with supporting competencies. One of the competencies needed is thinking skills [1]. By having appropriate thinking skills, someone will be able to think creatively, think strategically and make choices in the context of the world of work requires the promotion of critical thinking that has been developed previously [2]. Although it will be very challenging to be able to attract the attention of students in exploring the learning process that does not only require current knowledge, critical thinking will be very helpful in exploring things from the other possible sides. The implementation of curriculum that adopts critical thinking will be a challenge for both teacher and students, where learning English is directed at strengthening teacher and students to be more aware of the values and cultural and moral ideologies of their environment before making decision over something [3]. Thus, English language learning is not only the case of mastering linguistic competencies and communicative competencies. It is much further that students must be able to identify problems and solve problems in a rational 
way and desire to resolve conflicts and contradictions in a moral way, after integrating appropriate thinking skills.

High order thinking skills (HOTS) are expected to be a solution to realize this and have been integrated through the implementation of the 2013 curriculum in Indonesia to facilitate the development of graduates who are able to think better in analyzing a problem [4]. To be able to think critically, basic knowledge becomes necessary but does not play an important role in decision making. Its application in learning English becomes a challenge, because it can explore the role of culture in instilling an understanding that knowledge is socially formed, where students need to decode the ideological dimension of a problem to be analyzed and clarified [5]. In addition, developing thinking skills is not only needed in the the workplace, but also needed to solve the complexity of communication in family, community, and society [6]. In its application in the EFL classroom, developing ideas as an initial pattern of thinking to be able to analyze something and to conclude the case will be a good start in EFL pedagogy [7].

This research was conducted to find out two research focuses, namely:

What higher order thinking, if any, do the students exhibit in their responses to the controversial topic?

How would the students respond to the reaction of the controversial topic?

\section{Theoretical Framework}

\subsection{High Order Thinking Skills for Vocational School}

Thinking is a process of using intelligence to solve problems [8]. This process involves several activities in organizing ideas to make conclusions from knowledge or acquired abilities that can be used to solve other problems. In this process, someone is asked to compile information, concepts or other ideas and stimuli that could be expressed or implied. Critical thinking becomes a primary need in every educational framework. The ability to think creatively, make choices, solve problems, visualize, argue, analyze, interpret, and know how one learns may be a common definition of critical thinking [6].

In general, critical thinking can be divided into two, namely low order thinking skills and high order thinking skills. The relationship between low order thinking skills and high order thinking skills itself is on a continuum [9]. The implementation of thinking skills in selflearning does not need to be in order, as long as proper scaffolding is given [10]. In the application of learning, learning barrier may appear in operations at the higher order level thinking skills as in the following figure. 


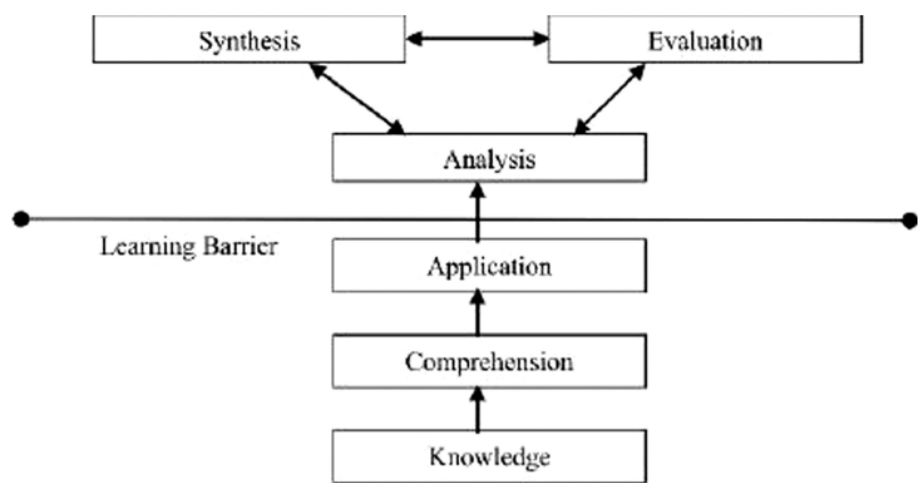

Fig 1 The learning barrier and Bloom's Taxonomy [2]

From figure 1, it can be said that the use of English as a foreign language in Indonesia to become a learning barrier is enough to make the head teacher confused. Nentl and Zietlow suggest using effective learning activities as stimulus needs to be given to attract students' attention to the learning barrier.

Learning in vocational schools in Indonesia has not yet integrated critical thinking in its subject matters. Being still oriented to the test prevents students from using their thoughts to process the information received [8], for further reviewing and completing the process of thinking skills in accordance with applicable norms and ethics [3].

Higher order thinking skills become an inseparable aspect of learning in secondary schools, because the pattern of early development to learn and solve problems needs to be honed not only from the routine of activities in the classroom, but also by explicit teaching and learning during the process in the classroom and outside the classroom [1].

\subsection{Responding to Controversial Topic}

The term controversial topic itself is rarely used in EFL / ESL learning, although classroom implementation is often used, especially in debates [11]. The use of controversial topics is very poorly discussed in the context of EFL/ESL. Controversial topics in the context of this study refer to the definition of Council of Europe on the concept of problems that invite human feelings and divide society or community into two or more views [12]. Furthermore, Sudha defines controversial topics as issues that affect the social, cultural, economic and environmental contexts in which humans live and relate to questions about values and beliefs that divide people into several views, whether between people, communities, or the wider community [13].

Teaching using controversial topics has been promoted in recent years [12]. Research conducted by Sudha [13] in a college context shows that the use of controversial topics can be used in promoting a more positive learning environment by paying attention to controversial topics used in the classroom.

According to the Council of Europe [12], the use of controversial topics in the classroom will greatly help shape learning competencies or competencies and community habits, where students are able 1) to promote a form of tolerance in giving opinions and appreciating the opinions of others, 2) to develop linguistic competencies and critical thinking in liters, and 3) to increase students' interest in things that are far more sensitive in the context of what they already know. Unfortunately, Council of Europe [12] mentions several problems that will be 
faced when teaching controversial topics, such as 1) teaching methods that may be too rigid, 2) difficulties in controlling students' emotions, 3) maintaining positive climate and class control, 4) lack of understanding of the topic, and 5) dealing with spontaneous questions.

\section{Method}

Participants of the study were 33 students in the 11th grade of a state vocational school in Bandung, Indonesia. These students ranged from 15-16 years old. The allotted time for the class was 125 minutes. The topic on the meeting was to give and respond to opinion about something.

Data is taken from students' written responses at the meeting. Written response as part of a performance test is suggested to measure higher order thinking skills because it is authentic and can accommodate complex life problems [14]. The stimulus given is asking students to respond to a social media player who is quite viral in Indonesia because he uses an application called tiktok. The stimulus given in class was a controversial topic and a reaction to controversial topics taken from YouTube that discussed the controversial topic.

Data analysis is done by using text analysis with Bloom's taxonomy [15] where intercoder agreement must be reached to determine the accuracy of text analysis. During the coding process, opinions from fellow researchers were asked for the purpose of validation. To ascertain the problem of trustworthiness, in the initial coding stage, fellow researchers were invited to discuss with researchers to discuss how students responded in the text and identify each text by using Bloom's taxonomy on the cognitive domain. In this identification process, researchers triangulated using an inter-coder agreement.

\section{Finding and Discussion}

Learning is carried out at one meeting for 125 minutes, which consists of three lesson hours. At the beginning of learning, students are directed to begin touching on technology, where this consideration is based on students coming from vocational schools and curriculum demands that ask students to give and respond to opinions. After preparation for learning was carried out, controversial topics were introduced. Learning about controversial topics is focused on topics related to technology, for example the use of social media applications. In relation to this study, researchers prepared two videos, where one video was about the viral figure and the second video was about the reaction video towards the viral figure. In class, students are directed to watch the first video that discusses a Youtuber who is quite viral because of a singing application and his attitude is quite confusing where he himself just started famous and held a meet and greet event while setting the rate for taking pictures together. After watching the video, students began to be asked to discuss their verbal responses to the controversial issue. After discussion, another video that discusses the response to Youtuber's issue was given and students were asked to pay attention to the style of the language, video content, and attitude of the respondent. After that, the teacher asks students to respond to how the controversial issue is and also the video response to the controversial issue.

In this connection, the first research question will discuss whether higher order thinking forms might arise in their response to the controversial topics discussed. The response of the 
students themselves varies greatly, from just giving a description of who Youtuber was to contrasting the idea.

The findings in the first question can be seen in the following table.

Tabel 1. Tabulation of Findings on Responses

\begin{tabular}{|c|c|c|}
\hline \multirow{2}{*}{ Taxonomy } & \multicolumn{2}{|r|}{ Response } \\
\hline & Total n. & Example \\
\hline Knowledge & 65 & Bowo is famous tik-tok player's, but his fans is idolize him to much \\
\hline Comprehension & 52 & $\begin{array}{l}\text { I don't know about Bowo, but I heard to my friend, and my friend } \\
\text { say Bowo have a problem in social media. }\end{array}$ \\
\hline \multirow[t]{2}{*}{ Application } & & $\begin{array}{l}\text { My oppinion of Bowo is too small kids for famous in tiktok } \\
\text { aplication }\end{array}$ \\
\hline & 54 & $\begin{array}{l}\text { Because tiktok is for people to make creative video on music to } \\
\text { video } \\
\text { but Bowo make the meet and greet like big artis and he make the } \\
\text { meet and greets is so expensive for the fans }\end{array}$ \\
\hline Analysis & 11 & $\begin{array}{l}\text { Due to his fame, Bowo was exposed to slander which resulted in } \\
\text { many people who did not like him }\end{array}$ \\
\hline \multirow[t]{2}{*}{ Synthesis } & & $\begin{array}{l}\text { In my oppinion, Bowo is a sensational artist. Many people dislike } \\
\text { him. }\end{array}$ \\
\hline & 4 & $\begin{array}{l}\text { I think that was miss understanding of Bowo and Bowo fans. Many } \\
\text { people dislike him, because Bowo fans idolize him too much. And } \\
\text { for me, whatever people want to like or dislike him for me, Bowo } \\
\text { dust Knowledge } 2 \text { years old kids and I think he is a good kids }\end{array}$ \\
\hline Evaluation & 0 & - \\
\hline
\end{tabular}

From table 1, it can be seen that there are high order thinking mentioned, despite being low in number. It is because the first research question focused on how students thought of Bowo as the controversial figure here. Many students, despite commenting to how they look at the problems, described Bowo's features, such as his appearance, his family, his fans, his haters, and so on. Rarely they look at how Bowo become problematic. Despite providing only descriptions, some students who admitted that they did not know Bowo related their background knowledge to predict and indicate a positive attitude toward him. Background knowledge is indeed important, but is not necessarily the most important part in making conclusion [10]. Students encounter learning barrier in this meeting, which was on

For the second research question, the focus is on how students respond to the video reaction towards the controversial topic. Students respond to the video with various perception. One of the students commented as in the following excerpt.

I think him don't take a mirror because he judge kids but he only kids.

The response is only an analysis of the video as the student did not elaborate further. The student appeared to judge the speaker in the video but there was no synthesis or evaluation on the video. Yet, another student appeared to provide the evaluation on the video as in the following excerpt.

About this video, I think it's good and not enough good too. He has good brave to make some channel by child and speak by English language for a while and I think that was good, because he doesn't afraid to be wrong and she is brave. But for the content, I think it's good, he give more info about what trending now. 
The response provided an elaboration on synthesizing his comments on two different point of views. Despite the mistakes on the grammar, this response has satisfactorily achieved the elaboration.

These two examples indicated an increase of interest on the reaction videos. It is in line with Council of Europe [12] that using controversial topics indeed arouse students' interest in that they may see things from different point of view. Yet, the lack of elaborated response may indicate that the instruction may not be sufficiently clear in that students seemed to not provide their responses to the reaction video. Explicit and clear instruction in the classroom is required to provide a clear guideline on what students should do [1], which is also apparent in what Council of Europe mentions that teaching style may influence how controversial topic should be delivered [12].

Higher order thinking skills tend to appear in the students' response, though the highest one is only on the synthesis. Further elaborated instruction to provide scaffolding to the student needs to be considered as it may enhance students' engagement in their thinking skills [10]. The selection on the controversial topic also needs to be considered, assuming that the absence of responses to the reaction videos was higher than the responses to the viral figure. The lack of understanding of the topic may be the case in that the teacher may further select which videos arouse students' interest, which enhance the effectiveness of the video to grab students' attention in the classroom [13]. Further considerations on students' interest, experience, and expertise should be done beforehand, as it greatly affects students' attitude in perceiving the controversial topic introduced in the classroom.

In short, there were responses indicating the use of higher order thinking skills in the responses to the viral figure, despite most responses only provided lower order thinking skills. Meanwhile, students' responses towards the reaction videos are much better in that lower order thinking skills appear less. Yet, there is a lack of the students' responses, which may indicate two possible causes, which are the selection of the topic and the lack of understanding of the topic.

\section{Conclusion}

The results of the study show that controversial topics are able to stimulate students to respond to a problem with a more complex mindset, as seen in the responses to the reaction videos rather than to the viral figure being discussed, than they normally do. Their responses shows that by connecting limited background knowledge, they begin to see problems from different sides. However, two possible causes may hinder the use of controversial topic, namely the selection of the topic and the lack of understanding of the topic. It is recommended to further explore the use of controversial topics to promote students' critical thinking, yet advise further research on how far controversial topic may be implemented in Indonesian EFL context.

Acknowledgment. The researchers would like to express their gratitude to the Ministry of Research, Technology and Higher Education of Republic of Indonesia, which had provided financial support through Program Dosen ke Sekolah. 


\section{References}

[1] C. C. Chinedu and Y. Kamin, "Strategies for Improving Higher Order Thinking Skills in Teaching and Learning Of Design and Technology Education," J. Tech. Educ. Train., vol. 7, no. 2, pp. 35-43, 2015.

[2] N. Nentl and R. Zietlow, "Using Bloom's Taxonomy to Teach Critical Thinking Skills to Business Students," Coll. Undergrad. Libr., vol. 15, no. 1-2, pp. 159-172, Jul. 2008.

[3] H. P. Widodo, M. R. Perfecto, L. Van Canh, and A. Buripakdi, "Incorporating Cultural and Moral Values into ELT Materials in the Context of Southeast Asia (SEA)," in Situating moral and cultural values in ELT materials: the Southeast Asian context, New York, NY: Springer Berlin Heidelberg, 2017.

[4] M. Sutarto, "Articulation of High Order Thinking Skills in Competency-Based Instruction in Indonesia Vocational and Technical High School," in Proceedings of the International Conference on Technology and Vocational Teachers (ICTVT 2017), Yogyakarta, Indonesia, 2017.

[5] A. Pennycook, "Critical pedagogy and second language education," System, vol. 18, no. 3, pp. 303-314, Jan. 1990.

[6] S. Kerka, "Higher Order Thinking Skills in Vocational Education.," 1992. [Online]. Available: https://www.ericdigests.org/1992-1/order.htm. [Accessed: 29-Sep-2018].

[7] W. Zinsser, Writing to Learn. New York: Harper Perennial, 1988.

[8] Y. M. Heong, J. B. Yunos, Noraini, Suzanna, and T. T. Kiong, "The Perception of Student on Mastering the Level of Higher Order Thinking Skills in Technical Education Subjects," p. 7, 2010.

[9] A. Churches, "Bloom's Digital Taxonomy," 2007. .

[10] J. L. McKinnon, "Effects of Scaffolding Higher Order Thinking Questions on Reader SelfEfficacy and Critical Thinking of Sixth Grade Students," Western Connecticut State University, 2012.

[11] A. Alasmari and S. S. Ahmed, "Using Debate in EFL Classes," Engl. Lang. Teach., vol. 6, no. 1, Dec. 2012.

[12] Council of Europe, "Teaching Controversial Issues," Council of Europe, 2015.

[13] M. M. Sudha, "Incorporating Controversial Issues in Critical Thinking Lesson: A Case Study of EFL Classroom," Engl. Lang. Teach., vol. 11, no. 9, p. 48, Aug. 2018.

[14] F. J. King, L. Goodson, and F. Rohani, Higher Order Thinking Skills: Definition, Teaching Strategies, Assessment. Educational Services Program, 2011.

[15] S. A. Rahman and N. F. A. Manaf, "A Critical Analysis of Bloom's Taxonomy in Teaching Creative and Critical Thinking Skills in Malaysia through English Literature," Engl. Lang. Teach., vol. 10, no. 9, p. 245, Aug. 2017. 